\title{
PERFORMA PENDIDIKAN KESEJAHTERAAN SOSIAL INDONESIA
}

\author{
Oleh: \\ Soni Akhmad Nulhaqim \\ (Email: soninulhaqim@yahoo.com)
}

\begin{abstract}
ABSTRAK
Pekerjaan sosial adalah sebuah profesi yang terus berkembang menjawab kebutuhan pelayanan sosial. Di Indonesia, pekerjaan sosial berkembang menjadi dua kategori yang diakui pemerintah, yaitu relawan sosial dan pekerja sosial profesional. Relawan sosial yang kegiatan yang bersifat charity dan philanthrophy dapat dilakukan oleh siapa saja dengan latar belakang apa saja. Namun demikian, pekerja sosial profesional adalah kegiatan yang didasari oleh pengetahuan, keterampilan dan nilai dalam menjawab kebutuhan pelayanan sosial. Pekerja sosial profesional merupakan lulusan dari pendidikan Ilmu Kesejahteraan Sosial yang ada di Indonesia. Ketersediaan pekerja sosial profesional tergantung pada performa pendidikan Ilmu Kesejahteraan Sosial di Indonesia. Kualitas pendidikan ilmu Kesejahteraan Sosial dapat didukung salah satunya dengan keberadaan Asosiasi Pendidikan Pekerjaan Sosial. Di Indonesia, asosiasi ini dikenal sebagai Ikatan Pendidikan Pekerjaan Sosial Indonesia (IPPSI). Ikatan pendidikan sangat penting dalam membangun kerjasama dan kesepakatan terkait dengan peningkatan kualitas pendidikan terkait dengan tuntutan perkembangan kebutuhan pekerja sosial profesional. Saat ini di Indonesia sudah terdaftar tiga puluh enam (36) sekolah yang mengajarkan pendidikan pekerjaan sosial/kesejahteraan sosial sebagai anggota dari IPPSI. 36 sekolah tersebut terbagi menjadi beberapa kategori kementerian, yaitu (10) perguruan tinggi negeri di bawah Kemendikbud, sembilan belas (21) perguruan tinggi swasta yang tergabung dalam Kopertis, satu (1) perguruan tinggi di bawah Kemensos, serta lima (4) perguruan tinggi di bawah Kemenag.
\end{abstract}

Kata Kunci: Pekerja Sosial profesional, Ikatan Pendidikan Pekerjaan Sosial Indonesia

\section{A. Pendahuluan}

Pada saat ini, terdapat dua kategori pekerja sosial yang diakui oleh pemerintah yaitu relawan sosial dan pekerja sosial profesional. Relawan sosial merujuk kepada seseorang yang berbuat amal atau memiliki kepedulian untuk berbagi dengan orang lain. Sedangkan pekerja sosial profesional adalah orang yang dasari oleh pengetahuan, keterampilan dan nilai dalam melakukan intervensi sosial terhadap permasalah sosial. Hal tersebut tercantum dalam Undang-undang Kesejahteraan Sosial No 11 Tahun 2011 yang menetapkan pekerja sosial profesional dan relawan sosial sebagai berikut :

Pekerja sosial profesional adalah seseorang yang bekerja, baik di lembaga pemerintah maupun swasta yang memiliki kompetensi dan profesi pekerjaan sosial, dan kepedulian dalam pekerjaan sosial yang diperoleh melalui pendidikan, pelatihan, 
dan/atau pengalaman praktek pekerjaan sosial untuk melaksanakan tugas-tugas pelayanan dan penanganan masalah sosial.

Relawan sosial adalah seseorang dan/atau kelompok masyarakat, baik yang berlatar belakang pekerjaan sosial maupun bukan berlatar belakang pekerjaan sosial, tetapi melaksanakan kegiatan penyelenggaraan di bidang sosial bukan di instansi sosial pemerintah atas kehendak sendiri dengan atau tanpa imbalan.

Terkait dengan UU No 112011 tersebut, maka pendidikan yang menghasilkan pekerja sosial profesional adalah pendidikan Jurusan Ilmu Kesejahteraan Sosial. Hal ini diperkuat juga dengan Peraturan Menteri Sosial No. 108 Tahun 2009 tentang Sertifikasi Pekerja Sosial Profesional dan Tenaga Kesejahteraan Sosial serta Peraturan Menteri Sosial No. 107 Tahun 2009 tentang Akreditasi Lembaga di Bidang Kesejahteraan Sosial.

Perkembangan lainnya, kebutuhan akan sumber daya yang berkualitas sebagai hasil penyelenggaraan pendidikan terus menjadi perhatian. Tak terkecuali, Jurusan Ilmu Kesejahteraan Sosial sebagai institusi pendidikan dimana lulusannya sebagai pekerja sosial profesional. Kontrol dalam penyelenggaraan pendidikan dilakukan melalui peraturan perundang-undangan misalnya melalui Badan Akreditasi Nasional Perguruan Tinggi (BAN-PT), Standar Nasional Pendidikan, Kerangka Kualifikasi Nasional Indonesia (KKNI), dan sebagainya.

Keberadaan asosiasi pendidikan menjadi sangat penting dalam membangun kerjasama dan kesepakatan terkait dengan peningkatan kualitas pendidikan terkait dengan tuntunan perkembangan seperti yang telah disebutkan di atas. IPPSI sebagai wadah bagi penyelenggara pendidikan kesejahteraan sosial di Indonesia memiliki tujuan yang mulia untuk membangun kesepakatan dan ikatan dalam meningkatkan dan mengembangkan pendidikan kesejahteraan sosial di Indonesia. Saat ini di Indonesia sudah terdaftar tiga puluh enam (36) sekolah yang mengajarkan pendidikan pekerjaan sosial/kesejahteraan sosial sebagai anggota dari IPPSI ini, meskipun masih banyak sekolah-sekolah lain yang mengajarkan pendidikan pekerjaan sosial/kesejahteraan sosial yang belum terdaftar sebagai anggota IPPSI.

Tentunya akan menjadi tantangan yang besar bagi pendidikan pekerjaan sosial/kesejahteraan sosial di Indonesia dalam menyambut tuntutan dan tantangan dalam perkembangan dunia pekerjaan sosial di Indonesia. Merujuk pada uraian tersebut di atas, tulisan ini akan mengkaji mengenai "Performa Pendidikan Kesejahteraan Sosial di Indonesia"

\section{B. Asosiasi Pendidikan Kesejahteraan Sosial Indonesia}

Ikatan Pendidikan Pekerjaan Sosial Indonesia pada awalnya dilakukan antara tiga lembaga pendidikan tinggi pertama yang mengajarkan pendidikan pekerjaan sosial yaitu STKS Bandung, Universitas Indonesia, serta STPS (sekarang STISIP Widuri) pada tahun 1967. Pertemuan awal tersebut membahas mengenai peran/tugasnya, serta kurikulum yang diperlukan dalam pendidikan pekerjaan sosial.

Selain lembaga pendidikan tinggi, pekerjaan sosial juga diajarkan pada jenjang pendidikan menengah yaitu di Sekolah Pendidikan Kemasyarakatan (SPK) yang dibentuk sekitar tahun 1948 untuk menangani masalah-masalah sosial sebagai dampak dari 
revolusi, yang didirikan setelah berdirinya Rehabilitation Center (RC) di Solo.

SPK kemudian dirubah menjadi Sekolah Pekerjaan Sosial Atas (SPSA) pada sekitar tahun 1960-an dengan lama pendidikan 4 tahun. Kemudian berubah menjadi Sekolah Menengah Pekerjaan Sosial (SMPS). Dalam perkembangannya, masa pendidikan di SMPS berubah menjadi 3 tahun. Kemudian, saat ini SMPS dikategorikan sebagai salah satu sekolah kejuruan atau Sekolah Menengah Kejuruan (SMK).

Pada tingkat akademi, terdapat Akademi Pendidikan Pekerjaan Sosial (APPS). Mahasiswa angkatan pertama, Jurusan Ilmu Kesejahteraan Sosial FISIP UI adalah lulusan APPS yang disetarakan dengan Sarjana Muda, namun harus menambah beberapa mata kuliah pada tingkat-tingkat sebelumnya yang belum diajarkan di APPS. Kalau antara APPS dan Fakultas/sekolah tinggi, sudah terlihat perbedaannya. Namun, antara SPSA dengan Perguruan Tinggi kurang jelas perbedaan karena sebagian pengajar adalah dari STKS yang dianggap paling mengerti tentang pekerjaan sosial, dengan landasan pengajaran yang sama. Sebagian pengajar di SPSA dan APPS adalah lulusan IKIP Bandung yang bekerja pada lembaga pendidikan, Departemen Pendidikan dan Kebudayaan dan departemen yang menangani masalah-masalah sosial. Dalam beberapa pertemuan ditetapkan bahwa lulusan SPSA adalah Pra Pekerja Sosial, dalam arti bahwa mereka belum dapat bekerja secara langsung. Tugas utamanya adalah pengumpul data, pengolahannya di bawah bimbingan APPS yang perannya sebagai Pra Pekerja Sosial. Sedangkan lulusan S1 adalah Pekerja Sosial yang memberikan bimbingan kepada lulusan APPS dan lulusan SPSA. Sekiranya dalam organisasi sosial hanya terdapat lulusan
SPSA, maka harus dibantu oleh yang pengetahuannya lebih tinggi dalam penanganan masalah sosial.

Sejak tahun 1967 tersebut, pertemuan rutin dilakukan namun belum berbentuk asosiasi. Kebutuhan akan adanya asosiasi pendidikan muncul setelah beberapa sekolah pekerjaan sosial mulai dikembangka di beberapa perguruan tinggi lain di Indonesia. Ikatan Pendidikan Pekerjaan Sosial Indonesia (IPPSI) akhirnya dibentuk pada tahun 1986 di STKS Bandung. Kepengurusan pertama asosiasi ini berakhir tahun 1990. Kepengurusan berikutnya, baru diadakan pada tahun 1996, tahun 2003, 2010, dan terkahir pada tahun 2012. Pada dasarnya, kepengurusan IPPSI selalu melibatkan wakilwakil dari Lembaga Pendidikan yang dipilih. Sehingga, hasil yang dicapai selama masa kepengurusan adalah hasil kerjasama antar beberapa Lembaga Pendidikan meskipun aktivitas sebenarnya hanya melibatkan beberapa orang.

Kegiatan-kegiatan awal IPPSI dimulai dengan tenaga-tenaga profesional yang masih terbatas. Meskipun demikian, kegiatannya tetap diusahakan untuk dilaksanakan. Dalam perkembangannya, muncul kebutuhan untuk membentuk organisasi yang terdiri dari lulusan pendidikan tinggi pekerjaan sosial/kesejahteraan sosial yang dapat memberikan masukan terhadap lembaga pendidikan, tentang kebutuhankebutuhan pekerja sosial di lapangan. Sehingga, dibentuk Himpunan Pekerja Sosial Indonesia (HIPSI) setelah IPPSI. Selanjutnya, IPPSI bersama HIPSI merangkul Dewan Nasional Indonesia untuk Kesejahteraan Sosial (DNIKS) sebagai lembaga yang mengorganisir organisasi-organisasi sosial dimana pekerja sosial bekerja. Sehingga, kegiatan awal IPPSI 
adalah memperkuat hubungan ketiga lembaga tersebut. Saat ini, keanggotaan Ikatan Pendidikan Pekerjaan Sosial Indonesia terdiri dari 36 sekolah yang terbagi menjadi sembilan (10) perguruan tinggi negeri di bawah Kemendikbud, sembilan belas (21) perguruan tinggi swasta yang tergabung dalam Kopertis, satu (1) perguruan tinggi di bawah Kemensos, serta lima (4) perguruan tinggi di bawah Kemenag.

\section{Perguruan Tinggi Penyelenggara Pendidikan Kesejahteraan Sosial/ Pekerjaan sosial}

Berdasarkan data dari asosiasi pendidikan pekerjaan sosial, Ikatan Pendidikan Pekerjaan Sosial Indonesia (IPPSI), diperoleh informasi mengenai jumlah perguruan tinggi penyelenggara pendidikan kesejahteraan sosial/pekerjaan sosial di Indonesia. Data tersebut menunjukkan bahwa terdapat tiga puluh enam (36) perguruan tinggi yang tersebar dari provinsi Nangroe Aceh Darussalam sampai provinsi Papua. Berikut sebaran perguruan tinggi penyelenggara pendidikan kesejahteraan sosial/pekerjaan sosial di Indonesia. 
Tabel 1 Perguruan Tinggi Penyelenggara Pendidikan Kesejahteraan Sosial/Pekerjaan Sosial

\begin{tabular}{|c|c|c|}
\hline NO & NAMA PERGURUAN TINGGI & ALAMAT \\
\hline 1 & IAIN Ar Raniry Banda Aceh & Kampus Darussalam, Banda Aceh \\
\hline 2 & $\begin{array}{l}\text { Universitas Muhammadiyah Sumatera Utara } \\
\text { (UMSU) }\end{array}$ & Kampus 1, Jalan Gedung Arca 53, Medan \\
\hline 3 & Universitas Sumatera Utara (USU) & Jl. Dr. A. Sofyan No. 1, Medan \\
\hline 4 & STISIPOL Candradimuka Palembang & Jl. Swadaya Basuki Rahmat, Palembang \\
\hline 5 & Universitas Bengkulu (UNIB) & Jalan Raya Kandang Limun, Bengkulu \\
\hline 6 & STISIP Widuri & J1. Pal Merah Barat 353, Jakarta Selatan \\
\hline 7 & Institut Ilmu Sosial dan Ilmu Politik (IISIP) & $\begin{array}{l}\text { Jalan Raya Lenteng Agung 32, Jakarta } \\
\text { Selatan }\end{array}$ \\
\hline 8 & Universitas Indonesia (UI) & $\begin{array}{l}\text { Gd. Nusantara Lt } 2 \text { Kampus FISIP UI, } \\
\text { Depok }\end{array}$ \\
\hline 9 & Universitas Muhammadiyah Jakarta (UMJ) & Jl. KH. Ahmad Dahlan, Ciputat \\
\hline 10 & UIN Syarif Hidayatullah Jakarta & J1. Ir. H. Juanda 95, Ciputat \\
\hline 11 & Sekolah Tinggi Kesejahteraan Sosial (STKS) & J1. Ir. H. Juanda 367, Bandung \\
\hline 12 & Universitas Galuh & J1. RE. Martadinata 150 , Ciamis \\
\hline 13 & Universitas Padjadjaran & $\begin{array}{l}\text { Jl. Raya Bandung Sumedang Km 21, } \\
\text { Jatinangor }\end{array}$ \\
\hline 14 & Universitas Pasundan & J1. Lengkong Besar 68, Bandung \\
\hline 15 & Universitas Langlang Buana & Jl. Karapitan 116, Bandung \\
\hline 16 & Universitas Garut & Jalan Raya Cimanuk 285A, Garut \\
\hline 17 & Universitas Negeri Sebelas Maret (UNS) & J1. Ir. Sutami 36A, Surakarta \\
\hline 18 & UIN Sunan Kalijaga Yogyakarta & J1. Marsda Adi Sucipto, Yogyakarta \\
\hline 19 & $\begin{array}{l}\text { Sekolah Tinggi Pembangunan Masyarakat Desa } \\
\text { "APMD" }\end{array}$ & Jl. Timoho 317, Yogyakarta \\
\hline 20 & Universitas Gadjah Mada (UGM) & Jl. Kaliurang Bulak Sumur, Yogyakarta \\
\hline 21 & Universitas Darul Ulum (UNDAR) & J1. Merdeka 29A, Jombang \\
\hline 22 & Universitas Muhammadiyah Malang (UMM) & Jalan Raya Tlogomas 246, Malang \\
\hline 23 & Universitas Muhammadiyah Ponorogo (UNMUH) & J1. Budi Utomo 10, Ponorogo \\
\hline 24 & Universitas Wijaya Kusuma Surabaya & J1. Dukuh Kupang XXV/54, Surabaya \\
\hline 25 & Universitas Jember (UNEJ) & Jl. Kalimantan II/24, Jember \\
\hline 26 & STISIP Muhammadiyah Madiun & Jl. Mayjen Panjaitan 18, Madiun \\
\hline 27 & Universitas Tanjungpura (UNTAN) & Jl. Jenderal Ahmad Yani, Pontianak \\
\hline 28 & Universitas Mulawarman & J1. Kuaro I/5, Samarinda \\
\hline 29 & Universitas Muhammadiyah Makassar & J1. Perintis Kemerdekaan Km 10, Makassar \\
\hline 30 & Universitas Teknologi Sulawesi & Jl. Abdullah Daeng Sirua 242, Makassar \\
\hline 31 & STIKS Tamalanrea Makassar & J1. Ammana Gappa 12, Makassar \\
\hline 32 & UIN Alaudin Makassar & J1. Sultan Alaudin 63, Makassar \\
\hline 33 & STIKS Manado & J1. Wolter Mongisidi VI/129, Manado \\
\hline 34 & Universitas Muhammadiyah Kupang & Jl. KH. Ahmad Dahlan 17, Kupang \\
\hline 35 & Universitas Kristen Indonesia Maluku (UKIM) & Jl. OT. Pattimaipauw, Ambon \\
\hline 36 & Universitas Cendrawasih & Jalan Raya Sentani Abepura, Jayapura \\
\hline
\end{tabular}


Dari data tersebut, dapat dilihat bahwa perguruan tinggi penyelenggara pendidikan kesejahteraan sosial/pekerjaan sosial tersebut dapat dibedakan berdasarkan kementerian yang menaunginya. Setidaknya terdapat tiga kementerian yang menaungi perguruan-perguruan tinggi penyelenggara pendidikan kesejahteraan sosial/pekerjaan sosial yaitu Kementerian Pendidikan dan Kebudayaan, Kementerian Sosial, dan Kementerian Agama. Kementerian Pendidikan dan Kebudayaan dapat diklasifikasikan menjadi Perguruan Tinggi Negeri (PTN) dan Perguruan Tinggi Swasta (PTS) yang dikoordinir oleh KOPERTIS. Dalam kajian ini, dipilih beberapa perguruan tinggi berdasarkan ketiga kementerian yang menangui perguruan tinggi penyelenggara pendidikan kesejahteraan sosial tersebut. Perguruan tinggi tersebut antara lain Universitas Padjadjaran, Universitas Bengkulu, Universitas Pasundan, Universitas Muhammadiyah Malang, Universitas Tanjungpura, Universitas Islam Negeri Sunan Kalijaga Yogyakarta, serta Sekolah Tinggi Kesejahteraan Sosial Bandung.

Perbedaan kementerian yang menaungi perguruan tinggi penyelenggara pendidikan kesejahteraan sosial/pekerjaan sosial tersebut, juga mempengaruhi kurikulum yang diterapkan di masing-masing perguruan tinggi. Khusus untuk perguruan tinggi di bawah Kementerian Agama misalnya, terdapat penekanan pada kurikulum yang berbasis Agama Islam yang sesuai dengan core business dari Kementerian Agama yaitu pendidikan agama Islam. Namun, kondisi tersebut tidak menjadi hambatan bagi penyelenggara pendidikan kesejahteraan sosial/pekerjaan sosial yang berada di bawah Kementerian Agama untuk tetap mengembangkan pendidikan kesejahteraan sosial/pekerjaan sosial yang selaras dengan perguruan tinggi lain.

Mengenai profil dosen di perguruan tinggi penyelenggara pendidikan kesejahteraan sosial/pekerjaan sosial, secara umum sudah menunjukkan kualifikasi dan kompetensi yang baik. Mayoritas dosen sudah menyelesaikan pendidikan di tingkat Magister atau S-2. Selain itu, mayoritas dosen juga mendapatkan gelar Sarjana dari Jurusan Ilmu Kesejahteraan Sosial. Namun, saat ini masih sedikit dosen yang berpendidikan Doktor yang mengajar di jurusan-jurusan penyelenggara pendidikan kesejahteraan sosial/pekerjaan sosial. Begitu pula dengan dosen yang mendapatkan penghargaan sebagai Guru Besar. Di Indonesia jumlah Guru Besar di bidang pendidikan kesejahteraan sosial/pekerjaan sosial masih di bawah sepuluh orang. Hal ini tentunya menjadi catatan bagi penyelenggara pendidikan kesejahteraan sosial/pekerjaan sosial, untuk terus mengembangkan kualifikasi dan kompetensi dosennya sehingga dapat menghasilkan lulusan yang baik.

Jika dilihat dari kondisi mahasiswa dan lulusan, kecenderungan jumlah mahasiswa baru di perguruan tinggi penyelenggara pendidikan kesejahteraan sosial/pekerjaan sosial terus mengalami peningkatan. Hal ini menunjukkan bahwa pendidikan kesejahteraan sosial/pekerjaan sosial sudah mulai dikenal di masyarakat. Kondisi tersebut bisa dimaknai secara positif maupun negatif. Secara positif berarti pendidikan kesejahteraan sosial/pekerjaan sosial mulai dibutuhkan di masyarakat. Di sisi lain, kondisi tersebut menjadi tantangan bagi penyelenggara pendidikan kesejahteraan sosial/pekerjaan sosial untuk terus meningkatkan kualitas pendidikannya. Selain itu, rata-rata penyelesaian masa studi di perguruan tinggi 
penyelenggara pendidikan kesejahteraan sosial/pekerjaan sosial tidak lebih dari 5 tahun atau sepuluh semester. Hal tersebut menunjukkan pencapaian yang cukup baik, meskipun masih menjadi catatan bagi penyelenggara pendidikan untuk memacu percepatan penyelesaian masa studi hingga mencapai angka ideal yaitu 4 tahun atau delapan semester.

Dari sisi users atau pengguna lulusan, pada umumnya lulusan pendidikan kesejahteraan sosial/pekerjaan sosial bekerja di berbagai bidang seperti pemerintahan pusat dan daerah, BUMN, BUMS, maupun di berbagai lembaga pelayanan sosial. Hal ini menunjukkan adanya kepercayaan dan kebutuhan terhadap lulusan pendidikan kesejahteraan sosial/pekerjaan sosial dari pihak pengguna lulusan. Selain itu, juga menunjukkan bahwa lapangan kerja bagi para lulusan pendidikan kesejahteraan sosial/pekerjaan sosial masih sangat terbuka lebar dan sanggup untuk bersaing dengan lulusan dari luar pendidikan kesejahteraan sosial/pekerjaan sosial.

Jika dilihat dari kurikulum pendidikan, saat ini penyelenggara pendidikan kesejahteraan sosial/pekerjaan sosial sudah menerapkan beberapa mata kuliah yang menjadi mata kuliah inti dalam kurikulum nasional pendidikan kesejahteraan sosial/pekerjaan sosial. Lokakarya kurikulum inti yang dilakukan oleh asosiasi pendidikan kesejahteraan sosial/pekerjaan sosial (IPPSI) merupakan upaya yang dilakukan oleh asosiasi untuk mewadahi aspirasi dan kebutuhan dari para anggotanya. Oleh karena itu, semua perguruan tinggi penyelenggara pendidikan kesejahteraan sosial/pekerjaan sosial yang menjadi anggota asosiasi dapat menerima dan akan menerapkan kurikulum inti yang sudah disepakati bersama.

\section{Penutup}

Dari hasil pembahasan dan analisa mengenai performa pendidikan kesejahteraan sosial/pekerjaan sosial di Indonesia, dapat ditarik beberapa hal yang menjadi kesimpulan. Di Indonesia saat ini terdapat tiga puluh enam perguruan tinggi yang menyelenggarakan pendidikan kesejahteraan sosial/pekerjaan sosial. Untuk melihat performa pendidikan kesejahteraan sosial di Indonesia, dapat dijelaskan dari kondisi eksisting yang ada di perguruan tinggi seperti dosen, mahasiswa, lulusan, serta kurikulum yang berjalan.

1. Dosen Ilmu Kesejahteraan Sosial di beberapa perguruan tinggi penyelenggara pendidikan kesejahteraan sosial/pekerjaan sosial pada umumnya berpendidikan Magister atau S-2. Selain itu juga, mayoritas berasal dari pendidikan sarjana Ilmu Kesejahteraan Sosial. Hal ini menunjukan bahwa dosen di perguruan tinggi penyelenggara pendidikan kesejahteraan sosial/pekerjaan sosial telah memiliki kompetensi yang sesuai untuk menjadi tenaga pengajar Ilmu Kesejahteraan Sosial.

2. Selama 5 tahun terakhir, jumlah mahasiswa Ilmu Kesejahteraan Sosial berjumlah lebih dari 50 mahasiswa setiap tahun akademiknya dan terus meningkat.

3. Sementara itu, mahasiswa Ilmu Kesejahteraan Sosial memerlukan 8 sampai dengan 10 semester untuk lulus. Lulusan ini memerlukan waktu 2,5 bulan hingga 3 tahun untuk mendapatkan pekerjaan. Dengan persentase sebanyak $70 \%$ hingga $84 \%$, lulusan ini terserap di pekerjaan yang sesuai dengan bidang Ilmu Kesejahteraan Sosial. Seperti CSR, Peneliti Sosial, Pengajar Ilmu 
Kesejahteraan Sosial, Lembaga Sosial Internasional serta lembaga pemerintahan seperti Dinas Sosial.

4. Sementara itu, 20 mata kuliah inti yang dihasilkan melalui lokakarya IPPSI umumnya telah terdapat pada kurikulum Ilmun Kesejahteraan Indonesia. Namun ada beberapa mata kuliah yang belum terdapat pada kurikulum sehingga perlu ditambahkan misalnya Mata Kuliah Supervisi.

\section{E. Saran}

$$
\text { Perlu diadakan upaya bagi }
$$
peningkatan kompetensi dosen seperti bantuan pendidikan sehingga dosen-dosen yang masih berpendidikan S-1 maupun S-2 dapat terbantu untuk dapat meningkatkan pendidikannya ke jenjang yang lebih tinggi.

Selain itu, terkait kurikulum yang diberlakukan di pendidikan Ilmu Kesejahteraan Sosial perlu adanya pemerataan sehingga lulusan yang dihasilkan dapat memiliki kompetensi umum yang sama. Hal ini dapat diwujudkan melalui penerapan mata kuliah inti IPPSI pada kurikulum di masingmasing perguruan tinggi.

\section{DAFTAR PUSTAKA}

Andrew, J., \& May, J.. 1995. Working in Human Service Organizations. Australia: Long Man.

Dubois, B., \& Miley, K. K. 1992. Social Work: An Empowering Profession. Boston: Allyn \& Bacon.

Gilbert,Neil \& Harry Specht. 1995. Handbook of the social services. Englewood Cliffs : New Jersey.
Lewis, Judith A., Michael D. Lewis, \& federico Soflee Jr. 1991. Management of Human Service Programs. Brooks/Cole Publishing Company: Pacific Grove, California.

Meyer, C. H., Mattaini, M. A. 1995. The Foundations of Social Work Practice. Washington: NASW Press.

Silalahi, Ulbert. 1997. Studi tentang Ilmu Administrasi. Bandung: Sinar Baru.

Weinbach, R. W. 1994. Social Worker as Manager. Allyn\& Bacon: Boston.

Yayasan Manajemen Bisnis \& Teknologi Independen. $t t$, Staffing Process for All Leaders (human resources management implementation) Training Program Module: (Tingkat Muda). Bandung: Lambert

Consult. 